\title{
Katarzyna Laskowska
}

Uniwersytet w Białymstoku e-mail: laskowska@uwb.edu.pl telefon: +48 7457158

DOI: $10.15290 / \mathrm{mhi} .2015 .14 .01 .20$

\section{Karnoprawne regulacje krwawej zemsty w Związku Radzieckim}

\author{
SUMMARY \\ Penal Regulations Concerning "Bloody Revenge" in the Soviet Union
}

In her study, K. Laskowska has presented the essence of the so called "bloody revenge" custom, peculiar to many USSR nations. She has shown a legal response to this 'relic of local customs' provided for in the Soviet criminal codes. She has endeavoured to demonstrate that neither the Soviet nor the modern state has managed to eliminate it from the lives of some societies, since their deep-rooted devotion to family tradition, sense of honour and justice has proven stronger than the statutory law. She stresses that it remains alive in many nations of the North Caucasus.

Key words: penal law, Soviet Union, bloody revenge

Słowa kluczowe: prawo karne, Związek Radziecki, krwawa zemsta

Przez wieki państwo rosyjskie stanowiło mozaikę kulturowo-religijną złożoną z narodów ją zamieszkujących. Owa różnorodność sprzyjała tworzeniu się lokalnych obyczajów i praw obowiązujących w tych wspólnotach. Na przestrzeni wielu lat wytworzyło się więc sporo norm charakterystycznych dla różnych narodów, dotyczących m.in. traktowania kobiety (jako panny i mężatki), honoru i czci rodu oraz rodziny, poczucia sprawiedliwości. Na kolejnych etapach rosyjskiej państwowości, dostrzegając pewne odrębności i osobliwości tych reguł, prawo różnorodnie na nie reagowało.

Na potrzeby niniejszego opracowania zdecydowano się przedstawić tylko jeden obyczaj utrwalony w części rosyjskiego i radzieckiego społeczeństwa obyczaj krwawej zemsty. Autorce publikacji wydało się interesujące poznanie jego fenomenu oraz zakresu kryminalizacji i penalizacji jako zachowania o charakterze przestępczym występującym w Związku Radzieckim. Zostanie 
on ukazany głównie w kontekście reakcji państwa wobec tego obyczaju i jego następstw. Podstawą do rozważań stały się radzieckie kodeksy karne oraz literatura prawnicza i kryminologiczna. Opracowanie ma charakter przeglądowo-informacyjny.

\section{Istota i charakter krwawej zemsty}

Przystępując do rozważań trzeba było dokonać operacjonalizacji pojęć używanych w dalszych analizach. Przyjęto więc, że obyczaj - „zasada postępowania, dobrowolnie przestrzegana przez wszystkich członków grupy społecznej" - jest uniwersalną normą regulującą stosunki społeczne, religijne i moralne ${ }^{1}$. Natomiast obyczaj krwawej zemsty stanowi „obowiązek krewnych zabitego dokonać zemsty na zabójcy lub jego bliskich"2.

W praktyce owa zemsta polegała na zabiciu sprawcy zabójstwa przez uprawnioną osobę, tj. członka rodziny zabitego. W zależności od specyfiki lokalnych obyczajów mogła polegać też na okaleczeniu sprawcy zabójstwa ${ }^{3}$. Wśród różnych narodów krwawa zemsta przejawiała się niejednorodnie: $w$ niektórych wystarczyło zabić jednego przedstawiciela wrogiego rodu, w innych obowiązek zemsty trwał tak długo, dopóki liczba ofiar po obu stronach była taka sama ${ }^{4}$. Na przestrzeni wieków, w różnych narodowościach, dokonanie jej spoczywało na kilku kategoriach osób bliskich zabitemu, np. pomścić brata mógł tylko brat, ojca - syn, syna - ojciec, syna siostry - brat siostry. Nie mogły w tym uczestniczyć kobiety ${ }^{5}$ W ich imieniu zemsty dokonywał mąż lub inni krewni płci męskiej. Bywało, że oprócz zabójstwa mszczono też porwanie kobiety, oszustwo, zniewagę, kradzież, bezczeszczenie wartości chrześcijańskich. Dokonywali tego nie tylko uprawnieni członkowie rodziny, ale także inni krewni6.

W tym miejscu rozważań należało ustalić: jaką rolę odgrywała w społeczeństwach krwawa zemsta i jaki miała charakter? Analiza szeregu opracowań prawno-kryminologicznych wskazała, że najczęściej stanowiła ona:

1 А.И. Аудоров, Объций кровной мести и правовые средства борьбы с ними, [w:] Российское правовое государство. Итоги формирования и перспективь развития, Воронеж 2004, s. 115.

2 Ibidem, s. 115.

3 Ю.М. Ткачевский, Преступления сотавляющие пережитки местных обыиаев, [w:] Советское уголовное право. Часть особенная, red. В.А. Меньшагин, Н.А. Аурманов, Г.А. Кригер, Москва 1971, s. 417.

$4 \quad$ А.И. Аудоров, ор. cit., s. 115.

5 М. Задворнов, А. Ааубеков, Обыиай кровной мести в ракурсе отечественного уголовного законодательства, „Уголовное право” 2010, nr 4, s. 25.

6 А.Ф. Маруков, М.Ю. Сергомасов, Кровная месть в Аревнерусском государстве, „Юридическая мысль" 2013, nr 1, s. 35-36. 
- „element systemów prawnych, w których państwo albo nie uczestniczy, albo nie jest w stanie zagwarantować porządku"7;

- „swoistą formę społecznej odpowiedzialności i szczególną formę wymiaru sprawiedliwości"8;

- regulator stosunków społecznych, który "gwarantował porządek, jedność i bezpieczeństwo wspólnoty w walce z wrogiem wewnętrznym"9;

- „uniwersalny środek obrony czci, godności i mienia rodu”10;

- „przejaw najbardziej niebezpiecznych form stosunków patriarchalno-feudalnych i rodowych" - jako jedno z przestępstw stanowiących przeżytki lokalnych obyczajów ${ }^{11}$;

- jedną z najbardziej niebezpiecznych form urzeczywistniania lokalnego obyczaju - ze względu na skutki ${ }^{12}$;

- w ZSRR - „spaczony przeżytek przeszłości”"13;

- odzwierciedlenie zasady talionu ${ }^{14}$;

- okrutny obyczaj według zasady: „śmierć za śmierć, rana za ranę, ząb za ząb"15;

- obowiązek krewnych pomścić pozbawienie życia ich krewnego, jego krzywdęi6;

- zmywanie krwi jednego człowieka krwią drugiego ${ }^{17}$;

- obowiązek, którego niewykonanie na Kaukazie „było wielkim grzechem i hańbą"18;

- „skrajny środek kompensacji za spowodowaną szkodę"19.

7 Ibidem, s. 34.

8 М. Задворнов, А. Ааубеков, ор. cit., s. 27.

9 С.В. Жильцов, Правовой обычай кроной мести, как иточник смертной казни древнерусского права, „Право и образование” 2012, nr 4, s. 120.

10 Р.А. Бармурзаева, Некоторье аспекты объиая кровной мести в республике Аагестан, „Современное право" 2012, nr 2, s. 105.

11 Н. И. Загородников, Преступления сотавляющие пережитки местных обыиаев, [w:] Советское уголовное право: Общая и особенная иасти, red. В.А. Меньшагин, Москва 1962, s. 455-456.

12 Н. В. Васильев, Преступления сотавляюшие пережитки местных обыиаев, [w:] Советское уголовное право. Особенная иасть, red. П.И. Гришаев, Б.В. ЗАравомыслов, Москва 1988, s. 556.

13 Н. И. Загородников, ор. cit., s. 456.

14 А.Ф. Маруков, М.Ю. Сергомасов, Кровная месть в Аревнерусском государстве, „Юридическая мысль" 2013, nr 1, s. 34.

15 М.А. Исмаилов, Институть обыиного права народов Аагестана. Кровная месть и система возмездия в обычном праве, „Закон и право” 2005, nr 6, s. 75.

16 И.М. Васильев, Преступления сотавляюшие пережитки местньх обычаев, [w:] Советское уголовное право: Общая и особенные части, red. Ю.В. Солопанов, Москва 1981, s. 444.

17 М.А. Шолько, Понятие кровной мести в науке российского права, Вестник У ситета. Правоведение 2003, s. 227.

18 А.П. Музюкин, Убийство по мотиву кровной мести в уголовном законодательстве, "Человек: преступление и наказание" 2009, nr 1, s. 84. 
Jak wynika z przedstawionych informacji, krwawa zemsta pełniła $\mathrm{w}$ życiu społeczeństw różne funkcje, przede wszystkim: sprawiedliwościową, represyjną i kompensacyjną. Była przydatna jako regulator stosunków społecznych.

Należy zaznaczyć, że jej rola malała wraz z rozpadem ustroju rodowego, a państwo wzięło na siebie obowiązek wymiaru sprawiedliwości ${ }^{20}$. Czy wówczas nadal stanowiła zagrożenie dla jednostek i państwa? Czy należało ją więc regulować prawnie, tj. kryminalizować? Z analizy dostępnych źródeł wynika, że zarówno w Rusi Kijowskiej, Imperium Rosyjskim, carskiej Rosji, jak i w państwie radzieckim prawo, w sposób mniej lub bardziej restrykcyjny, odnosiło się do tej kwestii.

\section{Regulacja krwawej zemsty w kodeksach karnych RSFSR z 1922 r. i z 1926 r.}

Do Rewolucji Październikowej z 1917 r. niektóre narodowości, zwłaszcza te, które zamieszkiwały tereny przygraniczne, żyły na niewysokim poziomie materialnym i kulturalnym, były słabiej rozwinięte od innych. Pod różnymi względami były eksploatowane i wykorzystywane przez lokalnych rządzących. Funkcjonowały według swoich zasad, opartych głównie na muzułmańskim prawie szariatu (na podstawie Koranu) i na prawie obyczajowym. Wraz z przyjęciem Deklaracji praw narodów Rosji z 15.11.1917 r. ${ }^{21}$, zakładającej równość i suwerenność wszystkich narodów oraz rozwój mniejszości narodowościowych zamieszkujących ten kraj, sytuacja się zmieniła. Grupy te zostały, bowiem, wdrożone $\mathrm{w}$ budowę nowego ustroju państwowego - komunizmu, zwalczającego stary ład i porządek społeczny, w tym „przeżytki lokalnych obyczajów”. Sądzono, że w ten sposób zostanie zagwarantowany równy rozwój narodów, w tym tych opóźnionych gospodarczo i kulturowo ${ }^{22}$. Realizację tego zadania wspomagać miało też prawo karne.

Jednakże w pierwszej redakcji kodeksu karnego RSFSR z 1922 r. ${ }^{23}$ nie przewidziano żadnego przepisu kryminalizującego dawne obyczaje. Dopiero

19 М.М. Омаров, У.Т. Саигитов, Кровная месть в Аагестане (на рубеже ХХ-ХХІ вв.), Махачкала 2006, s. 26. za: Р.А. Бармурзаева, Некоторые аспекты обычая кровной мести в республике Аагестан, „Современное право” 2012, nr 2, s. 107.

20 А.Ф. Маруков, М.Ю. Сергомасов, ор. cit., s. 39

21 Аекларация прав народов России от 15 ноября 1917 года, http://www.hist.msu.ru/ER/Etext/ DEKRET/peoples.htm.

22 Ю.М. Ткачевский, Преступления сотавляющие пережитки местных обычаев, [w:] Советское уголовное право. Часть особенная, red. В.А. Меньшанин, Н.А. Аурманов, Г.А. Кригер, Москва 1964, s. 391.

23 Постновление Всероссийского Центрального Исполнительного Комитета о введении в действие Уголовного кодекса РСФСР, www.library.ru. Kodeks został uchwalony 22 maja 1922 r., a wszedł w życie 1 lipca $1922 \mathrm{r}$. 
Postanowieniem Wszechrosyjskiego Centralnego Komitetu Wykonawczego z 1924 r. ${ }^{24}$ dodano do kodeksu część IX Бbıтовые преступления dotyczącą przestępstw związanych z obyczajami charakterystycznymi dla niektórych republik autonomicznych i obwodów RSFSR. Należy zauważyć, że katalogi tych przestępstw w poszczególnych republikach były różnorodne. Najczęściej skryminalizowane w nich czyny stanowiły: przyjęcie wynagrodzenia o charakterze majątkowym przez rodzinę od zabójcy lub jego rodu jako wykupu za niedokonanie na nim zemsty i kary, kradzież bydła lub innego mienia jak zemsta za krzywdę lub wynagrodzenie za wyrządzoną szkodę (бармта, барамта), płacenie okupu za pannę młodą jej rodzicom/krewnym (кальмм), zmuszenie kobiety do zamążpójścia, dwużeństwa lub wielożeństwo, porwanie lub pozbawienie wolności kobiety w celu zmuszenia jej do zamążpójścia, wstąpienie $\mathrm{w}$ związek $\mathrm{z}$ osobą niebędącą $\mathrm{w}$ wieku uprawniającym do zawarcia związku małżeńskiego. Jak wynika z przedstawionych informacji, wśród wymienionych przestępstw nie skryminalizowano krwawej zemsty, a jedynie wykup przed grożącą zemstą za popełnione zabójstwo. Zamieszczenie go w kodeksie karnym świadczyło o niedostrzeganiu zapobiegawczej roli tego wykupu.

Następnie obowiązujący kodeks karny RSFSR z 1926 r. ${ }^{25}$, także w pierwszej swej redakcji, nie zawierał żadnych przestępstw dotyczących obyczajów niektórych narodów radzieckich. Dopiero Postanowieniem Wszechrosyjskiego Centralnego Komitetu Wykonawczego z 6 kwietnia 1928 r. ${ }^{26}$ do kodeksu karnego RSFSR wprowadzono część X Преступления, составляющие пережитки родового бъıта ${ }^{27}$ (Przestępstwa stanowiące przeżytki obyczajowości rodowej). Stanowiły je: przyjęcie wynagrodzenia o charakterze majątkowym przez rodzinę od zabójcy lub jego rodu jako wykupu za niedokonanie na nim zemsty (art. 194), uchylanie się od ugody członków rodziny za-

24 Постановление Всероссийского Центрального Исполнительного Комитета от 16 октября 1924 года о дополнениях Уголовного кодекса Р.С.Ф.С.Р. для автономных республик и областей, http://www.libussr.ru/doc_ussr/ussr_2208.htm.

Постновление от 22 ноября 1926 года Всероссийского Центрального Исполнительного Комитета о введении в действие Уголовного кодекса РСФСР, www.soldat.ru.

26 Постановление ВЦИК от 06.04.1928 “О дополнении Уголовного Кодекса Р.С.Ф.С.Р. главой Х “О преступлениях, составляюших пережитки родового быта", примечанием 2 статьи 66 Земельного Кодекса Р.С.Ф.С.Р., примечанием к статье 11 и примечанием 3 к статье 26 Уголовно-Процессуального кодекса Р.С.Ф.С.Р.", http:// bestpravo.ru/sssr/eh-instrukcii/s1o.htm. Zob. też: Т.А. Аюжилова, А.Т. Хайруллин, Исследование группь преступлений, составляющих пережитки родового быта советской теорией уголовного права, „Проблемы в российском законодательстве" 2010, nr 2, s. 341.

Należy też wspomnieć, że w latach 1926-1936 przestępstwa stanowiące przeżytki związane $\mathrm{z}$ obyczajami niektórych narodów radzieckich wprowadzono też $\mathrm{w}$ kodeksach republik Armenii, Azerbejdżanu, Gruzji, Tadżykistanu, Turkmenistanu, Uzbekistanu. Ze względu na różnorodność narodowościowo-kulturalno-religijną katalog tych przestępstw w poszczególnych republikach był niejednakowy. Zob. Ю.М. Ткачевский, Преступления сотавляющие пережитки местных обычаев, [w:] Советское уголовное право. Часть особенная, red. В.А. Меньшагин, Н.А. Аурманов, Г.А. Кригер, Москва 1971, s. 407. 
bitego (art. 195), płacenie okupu za pannę młodą jej rodzicom/krewnym кальıм (art. 196), zmuszenie kobiety do zamążpójścia lub porwanie jej w tym celu (art. 197), wstąpienie w związek $\mathrm{z}$ osobą niebędącą w wieku uprawniającym do zawarcia związku małżeńskiego (art. 198), dwumałżeństwo lub wielożeństwo (art. 199), kradzież bydła lub innego mienia jak zemsta za krzywdę lub wynagrodzenie za wyrządzoną szkodę - бармта, барамта (art. 200), napady na przedstawicieli innych rodów na tle nienawiści (art. 201), stosowanie przemocy w związku z konfliktami na tle art. 200 i 201 kk (art. 202), przejęcie sądowych uprawnień przez obyczaje rodowe wykorzystujące zależność stron wynikających ze stosunków plemiennych (art. 203), wymuszanie opłat na cele religijne $\mathrm{z}$ jawnym wykorzystaniem zależności wynikających ze stosunków rodowych (art. 204).

Jak wynika z przedstawionych informacji, wśród wymienionych przestępstw, na pierwszy rzut oka, brak było przepisu kryminalizującego zachowania związane z krwawą zemstą. Jednakże po dokładniejszej analizie treści tych regulacji, należy stwierdzić, że wśród nich znajduje się jeden artykuł k.k. - art. 195 (przestępstwo uchylania się od ugody członków rodziny zabitego), który może, w pewnym zakresie, dotyczyć omawianego obyczaju.

W tym celu należało przedstawić zakres tego przestępstwa. Przepis art. 195 k.k. brzmiał: „uchylanie się członków rodu zabitego od pojednania się z zabójcą i jego rodem, ustanowionego $\mathrm{w}$ trybie przepisów o pojednawczym sposobie, a także sprzeciwianie się pojednaniu, podlega karze wydalenia poza granice danej miejscowości oraz obligatoryjnej lub fakultatywnej konfiskacie części mienia."

Należy zauważyć, że w sformułowaniu przepisu nie występuje określenie "krwawa zemsta" lub słowo „zemsta”, które są pojęciami kluczowymi w niniejszych rozważaniach. Zatem, może wydawać się, że treść tego artykułu bezpośrednio nie przesądza o odpowiedzialności zabójcy za uchylanie się od ugody mającej zapobiec (krwawej) zemście. Jednakże, należy rozumieć, że owo uchylanie się od pojednania dotyczy sytuacji związanych z ewentualnym odwetem, wendettą członków zabitego wobec zabójcy. Zatem w celu zapobieżenia agresywnym reakcjom mścicieli zabitego (krwawej zemście), uchwalono przepis w takim zakresie.

Ponadto, w celu pełniejszej realizacji art. 195 k.k. przyjęto też inną regulację dotyczącą pojednawczego sposobu w sprawie dotyczącej krwawej zemsty. Było nią Postanowienie Wszechrosyjskiego Centralnego Komitetu Wykonawczego i Rady Komisarzy Ludowych z 05.10.1928 r. ${ }^{28} \mathrm{Na}$ jego podstawie powstały komisje pojednawcze przy komitetach wykonawczych lokalnych rad. Ich zadaniem było ujawnianie przypadków krwawej zemsty, pojednywanie pokrzyw-

28 Постановление от 5 октября 1928 г. о примирительном производстве по борьбе с обычаем кровной мести, http://www.economics.kiev.ua/download/ZakonySSSR/data04/tex16643.htm. 
dzonych ze sprawcą, przekazywanie do sądu akt w celu pociągnięcia sprawców do odpowiedzialności karnej za zabójstwo lub uszczerbek na zdrowiu ${ }^{29}$. W ten oto sposób państwo dążyło do ugodowego zakończenia sporu na tle zabójstwa członka jednej z rodzin, a także do zapobieżenia samosądom i kolejnym przejawom przemocy.

Jak wynika z powyższych informacji, podejście ustawodawcy do krwawej zemsty na przestrzeni lat ewoluowało. Jednakże, zgodnie z panującą doktryną, funkcjonowanie tego obyczaju w społecznościach uznawane było za przeżytek, wymagający reakcji karnej.

\section{Regulacja krwawej zemsty w kodeksie karnym RSFSR z 1960 r.}

W następnie obowiązującym kodeksie karnym RSFSR z 1960 r. w części XI zawarto Преступления, составляюшие пережитки местных обыиаев (Przestępstwa stanowiące przeżytki lokalnych obyczajów). Stanowiły je: uchylanie się od ugody (art. 231 k.k.), zapłata i przyjęcie wykupu za kobietę (art. 232 k.k.), zmuszanie kobiety do wstąpienia $\mathrm{w}$ związek małżeński lub uniemożliwianie zawarcie związku małżeńskiego (art. 233 k.k.), zawarcie porozumienia w sprawie małżeństwa z osobą, która nie osiągnęła wieku małżeńskiego (art. 234 k.k.), dwu- lub wielożeństwo (art. 235 k.k.).

Jak wynika z analizy powyższego katalogu, wydaje się, że z obyczajem krwawej zemsty związane było przestępstwo uchylania się od ugody. Należało przeanalizować jego treść. Art. 231 k.k. z 1960 r. ${ }^{30}$ brzmiał: „uchylanie się krewnych zabitego od zrzeczenia się krwawej zemsty w stosunku do zabójcy i jego krewnych, realizowanego $w$ trybie ustanowionym przez przepisy o pojednawczym sposobie w sprawach dotyczących krwawej zemsty, podlega karze deportacji na okres do 2 lat lub wydalenia na okres do 3 lat".

Trzeba zauważyć, że w artykule tym ustawodawca w sposób bezpośredni posłużył się pojęciem „krwawa zemsta”. W czasie obowiązywania kodeksu z 1960 r. mogła wyrażać się ona w zamachu na życie lub zdrowie zabójcy, członków jego rodziny, a także bliższych i dalszych krewnych ${ }^{31}$.

Strona przedmiotowa przestępstwa z art. 231 kk z 1960 r. polegała na odmowie stawienia się $\mathrm{w}$ sądzie na posiedzeniu komisji pojednawczej lub na

29 Ю.М. Ткачевский, Преступления сотавляюшие пережитки местных обыиаев, [w:] Советское уголовное право. Часть особенная, red. В.А. Меньшагин, Н.А. Аурманов, Г.А. Кригер, Москва 1971, s. 417.

30 Уголовный кодекс РСФСР от 27 октября 1960 г., Ведомости Верховного Совета РСФСР от 31 октября 1960 года. № 40. ст. 591., http://www.lawrussia.ru/bigtexts/law_3558/. Kodeks wszedł w życie 1 stycznia $1961 \mathrm{r}$.

31 Н. В. Васильев, ор. cit., s. 556. 
odmowie podpisania dokumentu o zaprzestaniu krwawej zemsty ${ }^{32}$. Przedmiot przestępstwa stanowiły stosunki społeczne oraz jednostka.

Podmiotem przestępstwa był każdy krewny zabitego posiadający pełnomocnictwo do ugody/pojednania z rodem zabitego lub wskazany przez komisję do podpisania dokumentu o odstępstwie od krwawej zemsty ${ }^{33}$. Mogła nim być osoba wezwana przed komisję do pojednania, która ukończyła 16 lat $^{34}$. Strona podmiotowa polegała zarówno na umyślnym, jak i nieumyślnym zachowaniu w postaci spowodowania śmierci lub obrażeń ciała.

G.M. Mińkowskij zwracał uwagę, że przy krwawej zemście, jak i przy innych przestępstwach stanowiących przeżytki lokalnych obyczajów, sprawca w sposób jawny popełniał czyn zabroniony, będąc przekonanym o swoim prawie do takiego sposobu wymierzania sprawiedliwości ${ }^{35}$.

Wspomniane Komisje przy Radach Delegatów Ludowych składały się z przedstawicieli Komitetu wykonawczego (przewodniczący), sędziego ludowego, 2 przedstawicieli organizacji społecznych i przedstawiciela lokalnej organizacji kobiecej. Zbierały one informacje o osobach mających ze sobą konflikty na tle krwawej zemsty, wszczynały sprawy $\mathrm{z}$ tego powodu oraz pojednywały rodziny ofiary i sprawców. Podpisujący ugodę stwierdzał tym samym zakończenie prześladowania swoich przeciwników. W stosunku do osób, które nie zgłosiły się do komisji lub nie zgodziły się na odstąpienie od krwawej zemsty, komisja przesyłała kopie swoich akt do sądu w celu pociągnięcia do odpowiedzialności karnej ${ }^{36}$.

Ponadto, w kodeksie karnym z 1960 r. kryminalizowane było przestępstwo zabójstwa na tle krwawej zemsty (art. 102 pkt k) ${ }^{37}$.

W tym miejscu należy wskazać czynniki sprzyjające rozwojowi przestępstw - przeżytków, w tym krwawej zemsty. Stanowiły je: niewysoki poziom rozwoju kulturowego niektórych republik, wpływ islamu (szariatu), mankamenty pracy wychowawczej w lokalnych wspólnotach, brak efektywności upowszechniania

32 Ю.М. Ткачевский, Преступления сотавляющие пережитки местных обылаев, [w:] Советское уголовное право. Часть особенная, red. В.А. Меньшанин, Н.А. Аурманов, Г.А. Кригер, Москва 1964, s. 403; Н. И. Загородников, ор. cit., s. 457.

33 Комментарий к уголовному кодексу РСФСР 1960 г., red. М.А. Шаргородский, Н.А. Беляев, Менинград 1962, s. 385.

34 Н. В. Васильев, ор. cit., s. 555.

35 Г. М. Миньковский, Изуиение и предурждение преступлений сотавляющих пережитки местных объиаев, [w:] Криминология, Москва 1958, s. 451.

36 В.В. Шубин, Преступления сотавляющие пережитки местнъх обычаев, [w:] Комментарий к уголовному кодексу РСФСР, red. Ю.А. Северин, Москва 1984, s. 479.

37 Szerzej o zabójstwie na tle krwawej zemsty (art. 102 pkt k kk z 1960 r.) zob.: Г.И. Аиасамидзе, О некоторьх признаках умыпленного убийства на почве кровной мести, [w:] Проблемы әффективности угловного права. Сборник уиеных трудов, Выпуск 37, Свердловск 1974, s. 164 і n. 
norm prawnych dotyczących tych przestępstw ${ }^{38}$. Niewątpliwie istotną determinantą była hermetyczność wspólnot i przywiązanie ich do tradycji. W związku z tym trzeba zauważyć, że kodeksy karne republiki Litwy, Białorusi, Ukrainy, Łotwy, Estonii, Mołdawii nie przewidywały takich przestępstw ze względu na brak takich obyczajów na ich obszarze ${ }^{39}$.

Jednakże państwo radzieckie podjęło zdecydowane przedsięwzięcia wobec tych negatywnych zjawisk. Program partii podkreślał, że prowadzi walkę „przeciw obyczajom i narodom przeszkadzającym budowie komunizmu" ${ }^{40}$. W rzeczywistości celem ochrony ustawodawcy nie była ochrona życia ludzkiego, czy ochrona przed bezpośrednim zamachem ze strony innych jednostek, a tylko realizacja linii partyjnej i określonej ideologii ${ }^{41}$. W związku ze wdrażaniem programu partii stosunkowo szybko dostrzeżono efekty walki $\mathrm{z}$ przeżytkami. Już $\mathrm{w}$ latach osiemdziesiątych XX w. $\mathrm{w}$ czasie obowiązywania kodeksu karnego z 1960 r. „w rezultacie wielkiej wychowawczej i uświadamiającej pracy krwawa zemsta jako obyczaj stała się rzadkim zjawiskiem”" ${ }^{\prime 2}$. Podkreślano, że nie było łatwo do tego doprowadzić, gdyż „przeżytki przeszłości to jest straszna siła, która jak koszmar ciąży nad rozumami żyjących" 43 .

Podsumowując, prawo obyczajowe, w tym obyczaj krwawej zemsty, stanowiło $\mathrm{w}$ czasach radzieckich bardzo silną instytucję $\mathrm{w}$ niektórych społecznościach. Było istotne, zwłaszcza $\mathrm{w}$ tych, w których rodzina, wspólnota odgrywały dużą rolę. Jej wysoka pozycja wynikała z rodowego poczucia honoru i sprawiedliwości w najczystszej postaci. Pomimo realizacji przez państwo radzieckie prawnokarnej reakcji wobec krwawej zemsty, nie udało się tego obyczaju wyeliminować z życia niektórych narodów. Współcześnie występuje w Dagestanie ${ }^{44} \mathrm{i}$ innych republikach Północnego Kaukazu (Czeczenia, Inguszetia, Kabardino - Bałkarja, Północna Osetia) ${ }^{45}$. Ma więc nadal miejsce w życiu

$$
\text { DaC } \mathrm{C} \text { (e) }
$$
Аагестана. Кровная месть и система возмездия в объином праве, „Закон и право” 2005, nr 6; А.К. Халифаева, Ш.Н. Ажалилов, Кровная месть как институт обычного права Аагестана, „Юристь-правоведь” 2010, nr 1.

O historycznym kształtowaniu się krwawej zemsty ze szczególnym uwzględnieniem republiki 
tych społeczności ${ }^{46}$. Potwierdza to, że siła obyczaju jest nieraz we wspólnotach większa niż oddziaływanie prawa stanowionego/państwowego. Zatem, pomimo wieloletniej reakcji prawnokarnej, ani państwo radzieckie, ani współczesne definitywnie nie poradziło sobie $\mathrm{z}$ tą siłą.

\section{Bibliografia}

\section{Akty prawne}

Аекларация прав народов России от 15 ноября 1917 года, http://www.hist.msu. $\mathrm{ru} / \mathrm{ER} /$ Etext/DEKRET/peoples.htm.

Постановление Всероссийского Центрального Исполнительного Комитета от 16 октября 1924 года о дополнениях Уголовного кодекса Р.С.Ф.С.Р. для автономных республик и областей, http://www.libussr.ru/doc_ussr/ ussr_2208.htm

Постновление от 22 ноября 1926 года Всероссийского Центрального Исполнительного Комитета о введении в действие Уголовного кодекса РСФСР, www.soldat.ru.

Постановление Всероссийского Центрального Исполнительного Комитета от 16 октября 1924 года о дополнениях Уголовного кодекса Р.С.Ф.С.Р. для автономных республик и областей, http://www.libussr.ru/doc_ ussr/ussr_2208.htm

Постновление от 22 ноября 1926 года Всероссийского Центрального Исполнительного Комитета о введении в действие Уголовного кодекса РСФСР, www.soldat.ru.

\section{Literatura}

Барамия Б.И., Уголовноправовая борьба с преступлениями совершаемьми на почве кровной мести, [w:] Вопросы предупреждения преступности. Выпуск 2, Москва 1965.

Бармурзаева Р.А., Некоторые аспекты обыцая кровной мести в республике Аагестан, „Современное право” 2012, nr 2.

$\triangle$ Ашин А.В., Уголовно-правовые особенности квалификации обычая кровной мести на Севернм Кавказе, „Общество и право” 2012, nr 1.

46 Obecnie kodeks karny Federacji Rosyjskiej z 1996 r. nie kryminalizuje już przestępstwa uchylania się od ugody, zawiera jednakże przestępstwo zabójstwa na tle krwawej zemsty, a od 2007 r. - zabójstwa z motywu krwawej zemsty (art. 105 ust. 2 pkt 1). Szerzej o rozwiązaniach obecnie obowiązujących: М. Задворнов, А. Ааубеков, ор. cit., s. 27-28. 
$\triangle$ Аиасамидзе Г.И., О некоторьхх признаках умьиленного убийства на почве кровной мести, [w:] Проблемы әффективности угловного права. Сборник ученьхх трудов, Выпуск 37, Свердловск 1974.

Аудоров А.И., Объчиай кровной мести и правовые средства борьбы с ними, [w:] Российское правовое государство. Итоги формирования и перспективы развития, Воронеж 2004.

Аюжилова Т.А., Хайруллин А.Т., Исследование группь преступлений, составляющих пережстки родового быта советской теорией уголовного права, „Проблемы в российском законодательстве” 2010, nr 2.

Халифаева А.К., Ажалилов Ш.Н., Кровная месть как институт объиного права Аагестана, „Юристь-правоведь” 2010, nr 1.

Исмаилов М.А., Институть обьиного права народов Аагестана. Кровная месть и система возмездия в обычном праве, „Закон и право” 2005, nr 6.

Комментарий к уголовному кодексу РСФСР 1960 г., red. М.А. Шаргородский, Н.А. Беляев, Аенинград 1962.

Маруков А.Ф., Сергомасов М.Ю., Кровная месть в Аревнерусском государстве, „Юридическая мысль” 2013, nr 1.

Музюкин А.П., Убийство по мотиву кровной мести в уголовном законодательстве, „Человек: преступление и наказание” 2009, nr 1.

Омаров М.М., Саигитов У.Т., Кровная месть в Аагестане (на рубеже ХХ-ХХІ вв.), Махачкала 2006.

Миньковский Г. М., Изучение и предурждение преступлений сотавляющих пережитки местных обычаев, [w:] Криминология, Москва 1958.

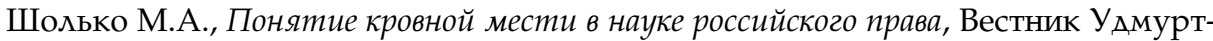
ского университета. Правоведение 2003.

Шубин В.В., Преступления сотавляюшие пережитки местных обыиаев, [w:] Комментарий к уголовному кодексу РСФСР, red. Ю.А. Северин, Москва 1984.

Ткачевский Ю.М., Преступления сотавляющие пережитки местных обычаев, [w:] Советское уголовное право. Часть особенная, red. В.А. Меньшанин, Н.А. Аурманов, Г.А. Кригер, Москва 1964.

Ткачевский Ю.М., Преступления сотавляюшие пережитки местньх обычаев, [w:] Советское уголовное право. Часть особенная, red. В.А. Меньшагин, Н.А. Аурманов, Г.А. Кригер, Москва 1971.

Васильев И.М., Преступления сотавляющие пережитки местньх обычаев, [w:] Советское уголовное право: Общая и особенные части, red. Ю.В. Солопанов, Москва 1981.

Васильев Н. В., Преступления сотавляющие пережитки местных обичаев, [w:] Советское уголовное право. Особенная иасть, red. П.И. Гришаев, Б.В. Здравомыслов, Москва 1988.

Задворнов М., Ааубеков А., Объичай кровной мести в ракурсе отечественного уголовного законодательства, „Уголовное право” 2010, $\mathrm{nr} 4$. 
Загородников Н. И., Преступления сотавляющие пережитки местных обыцаев, [w:] Советское уголовное право: Общая и особенная части, red. B.А. Меньшагин, Москва 1962.

Жильцов С.В., Правовой объций кроной мести, как иточник смертной казни древнерусского права, „Право и образование” 2012, nr 4.

Материаль ХХІІ Съезда Коммунистической Партии Советского Союза, Москва 1961. 